\title{
ARCHEOLOGIE KRAJINY OVLIVNĚNÉ VÝSTAVBOU VODNÍCH NÁDRŽÍ
}

KLíčovÁ SLOVA: archeologie současné minulosti, vodní nádrže, zaniklé vesnice KEYWORDs: archaeology of the contemporary past, water reservoirs, deserted villages

ÚvoD

Krajina českých zemí prošla v průběhu 20. století velkou proměnou. Kromě dlouhodobých procesů, jakými jsou například rozšiřování měst a zmenšování vesnického osídlení způsobené přirozenou urbanizací nebo zvětšení rozlohy lesů, která souvisí s vývojem využívání kulturní krajiny, ji postihlo i několik rychlých a dramatických proměn. Nevýraznější zásah přinesl jednoznačně poválečný odsun 3 milionů německých obyvatel především z pohraničních oblastí, který zaprř́činil zánik několika stovek lidských sídel a náhlou transformaci po staletí udržované kulturní krajiny v neobydlenou pustinu. Toto téma se v posledních letech těší v české archeologii relativně vysoké pozornosti a vzniklo několik studií věnovaných jednotlivým zaniklým obcím i celým pohraničním regionům (např. Vařeka a kol. 2008; Bureš 2012; Funk 2013). Kromě toho českou krajinu poznamenalo i několik menších lokálních zásahů. Zde jmenujme například rozsáhlou povrchovou těžbu hnědého uhlí (především v podhůř́i Krušných hor v dnešním Ústeckém kraji) a výstavbu velkých průmyslových komplexů (např. chemické továrny navázané na zpracování uhlí v Ústeckém kraji nebo jaderné elektrárny Dukovany a Temelín). V neposlední řadě se pak na podobě české krajiny podepsalo také zakládání velkých vodních nádrží, o nichž pojednává tato studie.

V průběhu 20. století vzniklo na území dnešní České republiky celkem 43 velkých vodních nádrží (velká vodní nádrž je kategorie definovaná Ministerstvem zemědělství České republiky. Těmto nádržím věnuje státní správa větší pozornost. Patří sem vodní díla od rozlohy 27 ha (Labská) do 4870 ha (Lipno). Kromě těchto 43 nádrží spadá do této kategorie i několik dodnes existujících středověkých a raně novověkých rybníků, které však nejsou předmětem této stu- 
die; Pokorný a kol. 2006: 16). Vliv těchto nádrží na podobu krajiny může být různý a odvíjí se od vlastností daného vodního díla. Nejdůležitějším atributem nádrže pro posouzení jejího vlivu na kulturní krajinu je její rozloha (vetší nádrže pochopitelně zasáhnou rozsáhlejší území než malé), nejedná se však o jedinou vlastnost. Jako zásadní se ukazuje především funkce vodního díla, konkrétně nádrže s vodárenskou funkcí (tj. shromažd’ování pitné vody) ovlivňují podobu krajiny mnohem více než nádrže s jinými funkcemi. Kolem takovýchto nádrží totiž ve většině případů vnikly ochranná pásma, $v$ nichž je zakázána jakákoliv hospodářská činnost, jež by mohla ovlivnit kvalitu vody v nádrže. Kvůli těmto ochranným pásmům v minulosti zaniklo mnoho lidských sídel, a to i v případech kdy se nalézaly několik kilometrů od břehu přehradního jezera. Dalším faktorem majícím vliv na působení nádrží na krajinu je předchozí využívání krajiny. Nádrže vybudované v málo obydlených zalesněných nebo horských oblastech krajinu proměňovaly mnohem méně než vodní díla, jež vyrostla v regionech, které do té doby pulzovaly lidskými aktivitami (Ván̆a 2016: 76-81).

Všechny tyto faktory musel před výstavbou nádrže zvážit její stavebník (tím byl u sledovaných vodních nádrží po celé 20 . století výhradně stát), který nakonec udělal rozhodnutí, zda ekonomické a jiné benefity vodního díla převáží nad jeho dopady na krajinu. Jak se měnily priority stavebníků přehrad lze snadno vypozorovat $\mathrm{v}$ počtu měst a vesnic zasažených vodními díly. $\mathrm{Z}$ tohoto pohledu lze vysledovat, že nejmenší vliv na sídelní sít' měly nádrže vybudované před vnikem samostatného státu v roce 1918. Naopak nejvíce lidských sídel zasáhla vodní díla postavená v 50. a 60. letech (obr. 1) (Váña 2016: 80-81).

Kromě těchto faktorů se vliv nádrží na proměnu kulturní krajiny mohl doplňovat i s jinými destabilizačními okolnostmi (např. výše zmíněný odsun německého obyvatelstva nebo rozsáhlá povrchová těžba).

Z toho všeho vyplívá, že výstavba vodní nádrže vždy přinesla do krajiny dramatickou změnu, která ve většině príípadů zcela přerušila nebo alespoň modifikovala dosavadní využívání krajiny. Doklady o původní podobě a hospodářské exploataci této krajiny $\mathrm{z}$ ní však $\mathrm{s}$ napuštěním přehradního jezera nevymizely. $\mathrm{Na}$ územích dotčených vodními nádržemi lze dodnes $\mathrm{v}$ zaplavených i nezaplavených oblastech nalézt mnohé hmotné pozůstatky po původní lidské činnosti. A právě ty se mohou stát předmětem archeologického zkoumání.

\section{Metody}

Pro poznání podoby krajiny před výstavbou velkých vodních nádrží ve 20 . století lze v českých zemích použít řadu kartografických pramenů. Velmi užitečnou pomůckou pro studium krajiny především 1. poloviny 20. století jsou tzv. mapy 3. vojenského mapování. Toto kartografické dílo sice vzniklo již v 70. letech 19. století, zhruba každé desetiletí však procházelo reambulací, a to až do 

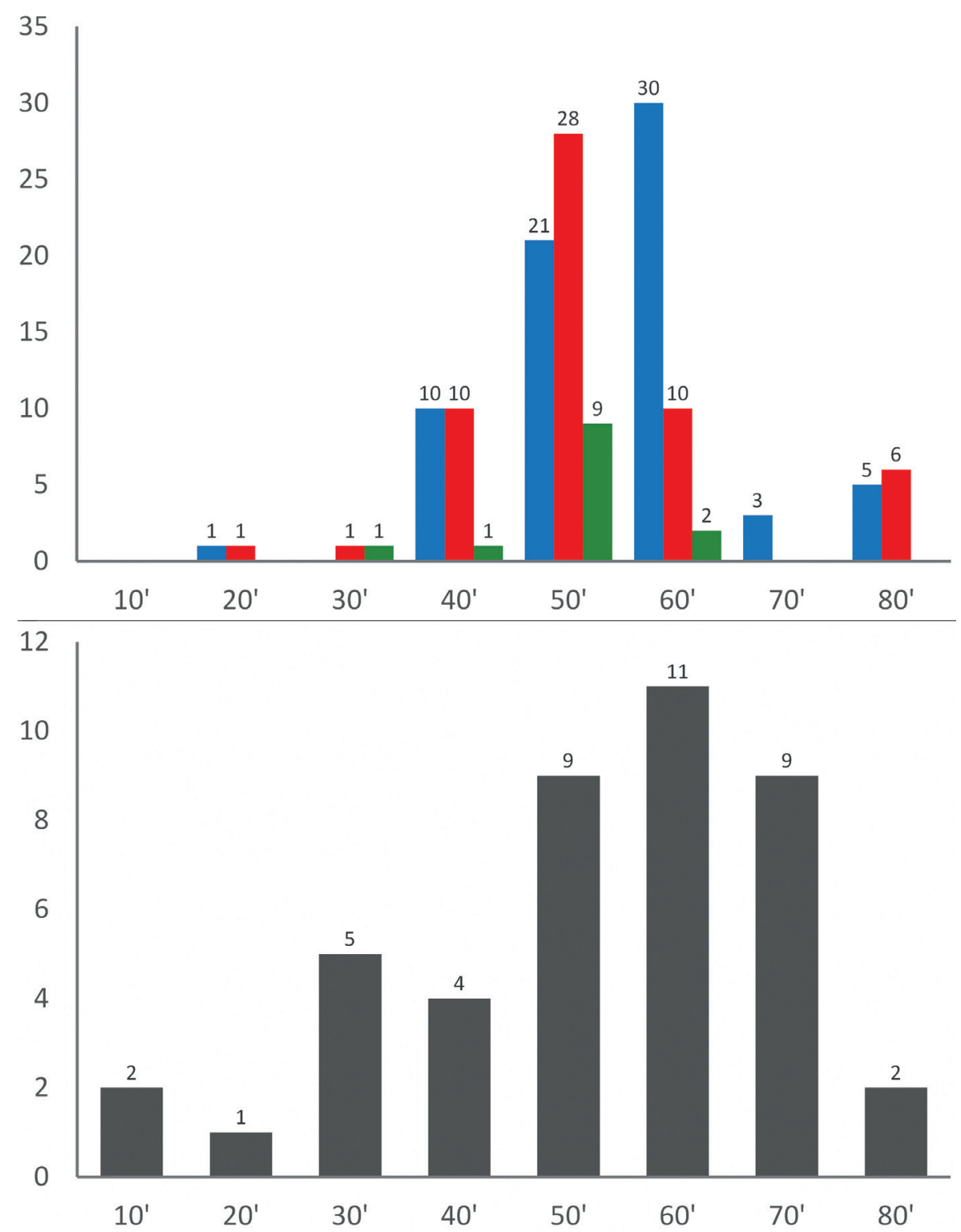

Obr 1. Horní graf ukazuje počty vesnic a měst zasažených výstavbou vodních nádrží rozdělené po desetiletích (modře zaniklá sídla, červeně redukovaná, zeleně přenesená na jiné místo). Spodní graf zobrazuje počty zahájených výstaveb velkých vodních nádrží. Z grafů vyplívá, že největší vliv na lidská sídla měla vodní díla z 50. a 60. let. Počet měst a vesnic zasažených $\mathrm{v}$ tomto období kontrastuje zvláště se 70 . lety, kdy se však zahájila výstavba stejného počtu nádrží (grafika M. Váňa). 
počátku 50. let 20. století. Tyto mapy, jež jsou k dispozici v měřítku 1:25000 a 1:75 000, zobrazují reliéf v podobě vrstevnic a spádnic, města a vesnice včetně jednotlivých staveb, sít komunikací a vodotečí, plochy lesů a hospodářské a industriální budovy. Krajinu 2. poloviny 20. století pak umožnují studovat Topografické mapy systému S-1952, které vznikly na počátku 50. let a až do 70 . let byly v intervalu zhruba 3-5 let reambulovány. Tyto mapy existují v různých měřítcích od 1:10 000 do 1:500 000 a pro zájemce o vývoj sídelní struktury mohou být zajímavé především tím, že speciálními značkami rozlišují opuštěné stavby a budovy určené $\mathrm{k}$ demolici. V posledních letech se ke zkoumání minulé krajiny začínají též využívat velmi podrobné kolmé letecké fotografie, jejichž sbírku spravuje a postupně zveřejňuje Vojenský geografický a hydrometeorologický úřad v Dobrušce spolu s Českým úřadem zeměměřickým a katastrálním. S kolmým leteckým fotografováním se v bývalém Československu experimentovalo už od konce 30 . let, od 50. let pak bylo prováděno pravidelné snímání celého území státu. Tyto snímky, které se původně pořizovaly pro potřeby armády, bývají často velmi detailní a umožnují nám podrobně poznat podobu kulturní krajiny před kataklyzmatickými událostmi, které ji v 2. polovině 20. století potkaly. Badatelům jsou tyto fotografie dostupné v podobě ortofotomapy složené ze snímků především z 50. let ve webové aplikaci Kontaminace ${ }^{1}$. Jednotlivé doposud zveřejněné letecké snímky lze pak najít v aplikaci LMS ČÚZK²

$\mathrm{K}$ poznání stavu krajiny $\mathrm{v}$ době před tím, než do jejího vývoje vstoupila výstavba vodní nádrže, se kromě map používají i jiné výtvarné a audiovizuální prameny, např. kresby a malby, fotografie nebo osobní videozáznamy. O většině velkých vodních nádrží z 2 . poloviny 20 . století navíc v době jejich výstavby vznikly dokumentární filmy, které kromě technických parametrù vodního díla a zajímavostí z jeho budování často obsahují komentované záběry na krajinu, kterou se filmovaná nádrž chystá zaplavit. Velká část těchto dokumentů byla publikována v televizním opusu Karla Čáslavského Hledání ztraceného času, který je $\mathrm{k}$ dispozici $\mathrm{v}$ internetovém archivu České televize ${ }^{3}$. Některé vodní nádrže také posloužily jako kulisy v hraných filmech. Jako př́klad uved'me kriminální drama z roku 1959 Konec cesty od režiséra Miroslava Cikána, v němž se objeví staveniště přehrady vodní nádrže Fláje (dnešní Ústecký kraj) a stejnojmenná vesnice, která kvưli této nádrži zanikla.

Co se týče samotného terénního archeologického průzkumu, ten je nutný $\mathrm{v}$ prostředí vodních nádrží z metodologického hlediska rozdělit na dvě odlišné části: na výzkum zaplavených území a nezaplavených území v okolí nádrže. Bádání v nezaplavených plochách se v zásadě neliší od běžného terénního ar-

\footnotetext{
${ }^{1} \mathrm{http} / / /$ kontaminace.cenia.cz (dostupné: 7.03.2017).

${ }^{2}$ http://lms.cuzk.cz/lms (dostupné: 7.03.2017).

${ }^{3}$ http://www.ceskatelevize.cz/porady/873537-hledani-ztraceneho-casu (dostupné: 7.03.2017).
} 
cheologického výzkumu a lze při něm použít celou škálu archeologických metod od prosté vizuální prospekce po progresivní metody leteckého laserového skenování.

Odlišná situace však panuje u výzkumu archeologických reliktů pohřbených na dně přehradních jezer. K jejich zkoumání by bylo možné využít metod podvodní geofyziky (pro potřeby archeologie se v zahraničí nejčastěji užívají metody založené na akustice a magnetometrii; Firth 2010: 132-135), ty však v českém prostř̌edí zatím nikdy nebyly aplikovány. Ke snímání vodního dna by šlo využít i letecké laserové skenování, skenovací přístroj by však musel být nastaven na vysílání paprsků o specifické vlnové délce, která by byla schopna projít vodní hladinou (Dolanský 2004: 73-74). Data z takovýchto př́ístrojů však nejsou v České republice komerčně dostupná.

Zatopené památky lze také zkoumat potápěčským průzkumem, který se v posledních letech začíná v české archeologii pomalu rozvíjet. V jeho čele stojí od roku 2014 Spolek pro podvodní archeologii, který je složen z archeologů převážně z brněnské Masarykovy univerzity ${ }^{4}$. Jeho hlavní zájem se však prozatím soustředil především na pravěké památky. Malý zájem archeologů o pozůstatky kulturní krajiny pohřbené na dně vodních nádrží ale bohatě vyvažují spolky potápěčských nadšenců. Za všechny jmenujme Willyteam ${ }^{5}$, který na svých ponorech dokumentuje především památky na dnech nádrží Orlík a Slapy, nebo v Plzni působící klub OSAC ${ }^{6}$, jenž se potápí do zaniklých vesnic ve vodní nádrži Hracholusky. Na stránkách těchto klubů lze nalézt množství fotografií dokumentujících dodnes existující pozůstatky zatopené kulturní krajiny, jakými jsou ruiny domů, podstavce soch nebo zbytky industriálních objektů.

Na závěr je potřeba zmínit, že i zaplavené památky se ve výjimečných případech zpř́istupňují metodám běžné „suchozemské“ archeologie, a to při dostatečném poklesu hladiny ve vodní nádrži. $\mathrm{K}$ této situaci může dojít během dlouhodobého sucha, jako se tomu stalo třeba v roce 2012 na vodní nádrži Žlutice (Karlovarský kraj). Voda v nádrži zde tenkrát poklesla natolik, že odhalila pozůstatky zaniklé vesnice Mlýňany, která za běžných okolností zůstává z větší části zaplavená. K významnému snížení hladiny dochází i při rekonstrukcích přehradních těles, které se však provádí jen jednou za mnoho let. Tato vzácná událost nastala třeba v roce 2015, kdy oprava přehrady vodní nádrže Fláje odhalila stejnojmennou zatopenou vesnici.

\footnotetext{
${ }^{4} \mathrm{http}: / /$ podvodniarcheologie.cz (dostupné: 7.03.2017).

${ }^{5} \mathrm{http}: / /$ www.willyteam.cz (dostupné: 7.03.2017).

${ }^{6} \mathrm{http}: / /$ www.osac.cz (dostupné: 7.03.2017).
} 


\section{Př́́KLAdY PaMÁteK}

Při výzkumu minulé krajiny, do jejíhož vývoje zasáhla výstavba vodní nádrže, se badatel může setkat s celou řadou archeologických objektů. Tato kapitola představuje tři typy památek, které se $\mathrm{v}$ tomto prostředí mohou objevit. Jedná se o vesnici, jež zanikla v souvislosti s vytyčením ochranného pásma pro vodárenskou nádrž, komunikaci, která ztratila svůj význam poté, co byla přetata přehradním jezerem, a jednu zajímavou technickou památku, která se kvůli vodní nádrži nedočkala svého dokončení.

\section{ZANIKLÁ VeSNICE FLÁJE}

Zaniklá obec Fláje se nachází v údolí flájského potoka, ve vrcholových partiích Krušných hor, asi 20 km severně od Mostu (Ústecký kraj). První zmínka o vsi pochází z roku 1346. Po celou historii byly Fláje domovem především lesních dělníků, kteří v krušnohorských lesích těžili dřevo pro potřeby saských hutí (Sýkorová 2002: 25). V 17. století zde vznikl 18 km dlouhý plavební kanál Fláje - Clausnitz, který se ve většině svého průběhu dochoval dodnes (Joza 2002: 20-25). Další významnou památkou byl dřevěný kostel sv. Jana Křtitele ze 17. století. Podle sčítání lidu z roku 1950 se ve Flájích nacházelo 100 domů, v nichž žilo 192 lidí (Kolektiv 1978: 513). Na přelomu 50. a 60. let však Fláje musely ustoupit stejnojmenné vodní nádrži. Ta zaplavila zhruba třetinu intravilánu obce, kvůli ochrannému pásmu pro pitnou vodu však musel zaniknout i zbytek vsi. S výjimkou jednoho domu, který dnes slouží jako hájovna, byly všechny budovy ve Flájích zbořeny. Vzácný dřevěný kostel sv. Jana Křtitele byl však naštěstí včas přemístěn do sousední obce Český Jiřetín.

Výzkum Flájí probíhal v roce 2015, kdy vlivem oprav na přehradním tělese došlo $\mathrm{k}$ výraznému poklesu hladiny nádrže, který odhalit většinu zaplavené části intravilánu zaniklé vsi. Během terénního průzkumu se podařilo identifikovat několik desítek reliktů zbořených budov, které se na lokalitě projevují jako haldy stavební suti, $v$ jejichž struktuře je ve většině př́ípadů stále čitelný půdorys a vnitřní členění původní stavby (obr. 2). Velmi zajímavé relikty pak bylo možné pozorovat $\mathrm{v}$ místech, které se za běžného stavu hladiny v nádrži nacházejí na břehu přehradního jezera. Zde vlivem kolísání hladiny došlo k rozplavení stavení suti a do značné míry i terénu kolem zbořených budov, což vedlo k odhalení zděných kleneb sklepů (obr. 3).

V nezaplavené části lokality zůstala pietně zachována podezdívka přeneseného kostela, která tak návštěvníkům ukazuje původní půdorys této stavby. S mnohem menší pietou se však naložilo se hřbitovem, který se rozprostíral kolem kostela. Všechny náhrobky se dnes nacházejí na hromadě při severním okraji lokality. 


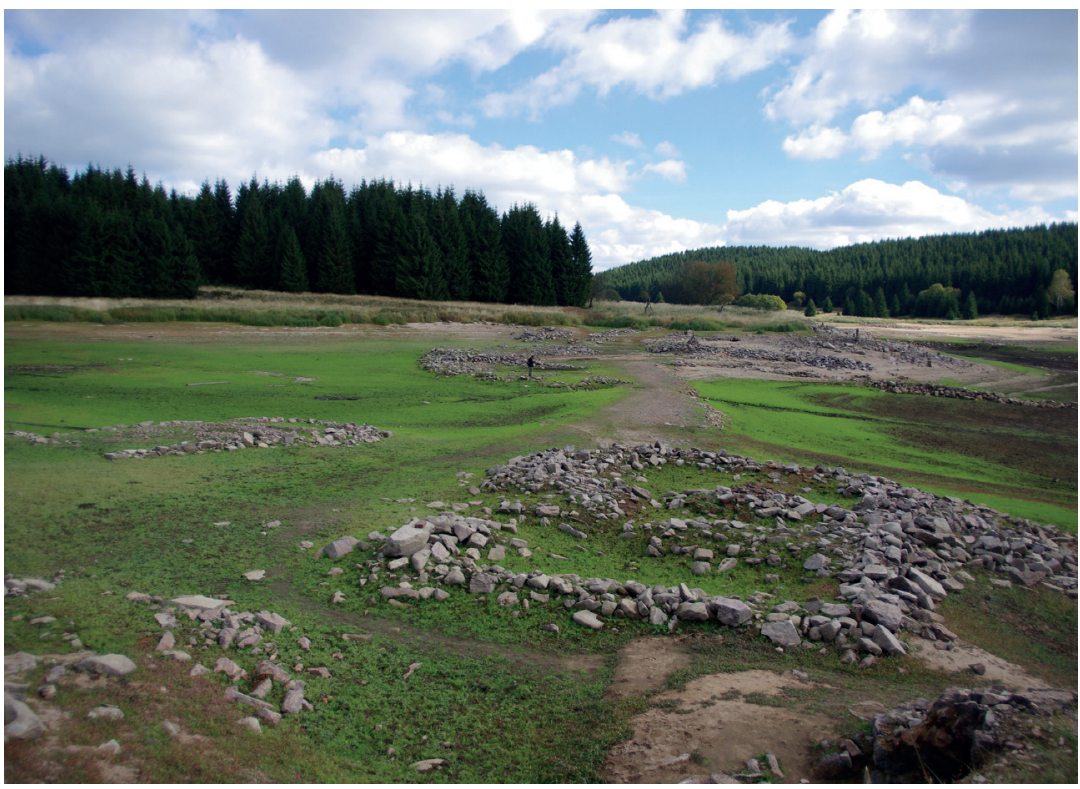

Obr. 2. Relikty zbořených budov v zaniklé vsi Fláje mají podobu hald stavební suti, v nichž je stále patrný půdorys a vnitřní členění původních staveb (foto L. Funk, záŕí 2015).

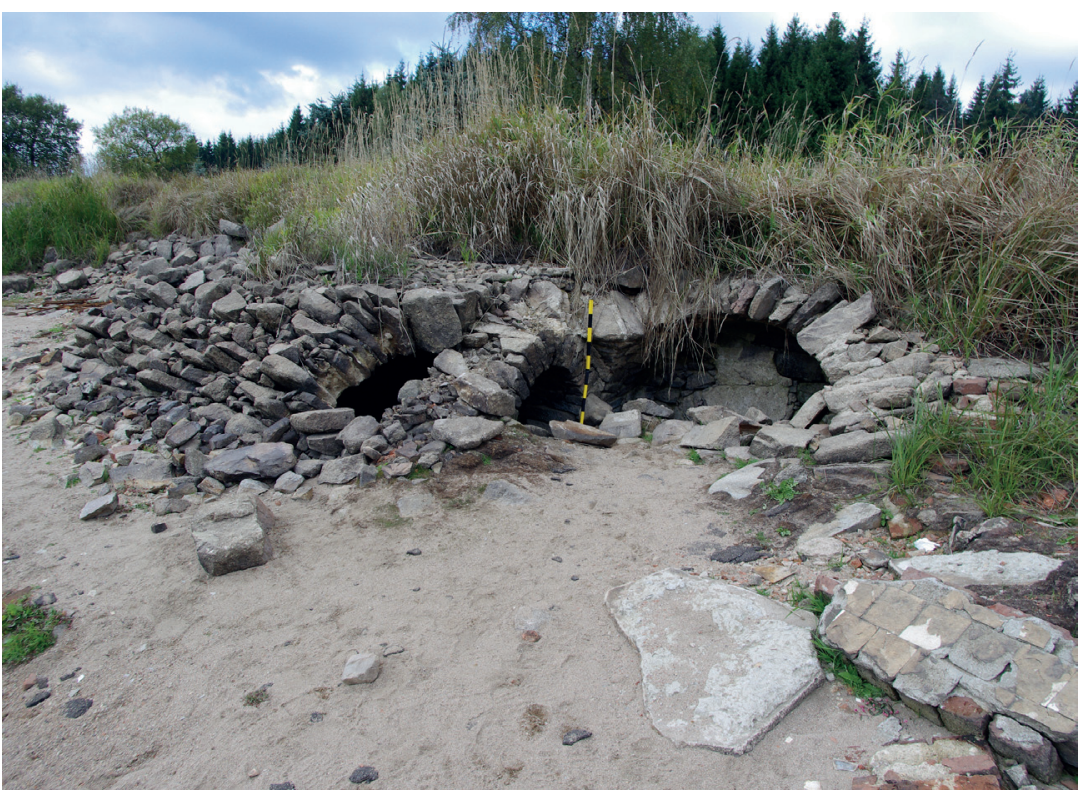

Obr. 3. Klenby sklepů zbořených budov odhalené díky vodní erozi (foto L. Funk, září 2015). 
V oblastech, jež obvykle bývají zaplavené, se podařilo identifikovat i silnici, která procházela celou obcí. Ta se zde projevuje jako 3-5 m široký pás štěrku a drobných kamenů vniklý rozplavením lehčích složek povrchu komunikace. Na této silnici se navíc dodnes dochovaly dva mosty (obr. 4).

Fláje představují pro prostředí vodárenských nádrží typickou lokalitu. S antropogenními relikty, jako jsou pozůstatky zbořených budov, se můžeme setkat i v jiných vesnicích, jež byly zrušeny kvůli ochrannému pásmu pro pitnou vodu. Díky dramatickému poklesu hladiny v roce 2015 se však podařilo identifikovat i mnohem vzácnější relikty, jakými jsou zatopené mosty nebo odhalené klenby sklepů.

\section{ZRUŠENÝ ÚSEK ŽELEZNIČNí TRATI ČERNÁ HŮRKA - ŽELNAVA}

Železniční trat' z Českých Budějovic do šumavské obce Želnava byla postavena v letech 1890-1892. Roku 1910 pak došlo k protažení této trati ze Želnavy do Volar, kde se železnice napojila na již existující trat' mezi Prachaticemi a Vimperkem. Tato dráha $\mathrm{z}$ počátku sloužila především $\mathrm{k}$ přepravě dřeva $\mathrm{z}$ rozsáhlých šumavských lesů, využívala se však i $\mathrm{k}$ civilní dopravě a v podstatě stála na počátku turistického boomu v šumavském pohoří (Rebstöck 2013: 62-64). V 50. letech 20. století pak v údolí Vltavy vyrostla největší česká vodní nádrž Lipno, která pošumavskou železnici přetala. Kvưli lipenské nádrži byl zrušen zhruba 12 km dlouhý úsek dráhy mezi stanicemi Černá Hůrka a Želnava, který nahradila nová přeložka vedoucí po severním břehu přehradního jezera.

Přibližně polovina délky zrušeného drážního úseku se dnes nachází na dně lipenské nádrže, nezaplavená část je však dodnes dobře zachovaná (obr. 5). Původní průběh trati lze rozpoznat i na leteckých snímcích, nebot' na bývalém železničním náspu často roste oproti okolí odlišná vegetace (obr. 6).

$\mathrm{K}$ terénnímu průzkumu, jenž se odehrál $\mathrm{v}$ roce 2014, bylo vybráno několik nezaplavených úseků zrušené trati. Jednalo se především o část, jež dnes kopíruje jižní břeh vodní nádrže Lipno. Zaniklá železnice se zde projevuje jako (často i několik metrů vysoký) násep. Na celém zkoumaném úseku nebyly nalezeny žádné pozůstatky kolejí, dodnes se zde však zachovaly relikty dvou železničních mostů. Z prvního z mostů, který překonával Smrčinský potok, zbyly dvě mostní opěry zděné bosovanými kvádry (obr. 7). Jeden z kvádrů zdobí kaligraficky vyvedený letopočet 1916. Z mostu se nezachovaly žádné železné konstrukce. Avšak po druhém mostu, jenž se nacházel na potoku Šešovec, zbylo ještě méně. Tento most dnes nalezneme na místě, kde násep zaniklé železnice přetíná jednu ze zátok lipenské nádrže. Zřejmě kvůli lepší cirkulaci vody v této zátoce byl most zbourán a dnes na jeho místě nalezneme jen přerušený násep a několik po okolí se povalujících kvádrů, které se tvarem i opracováním shodují s materiálem, z něhož byl postaven i most přes Smrčinský potok. 


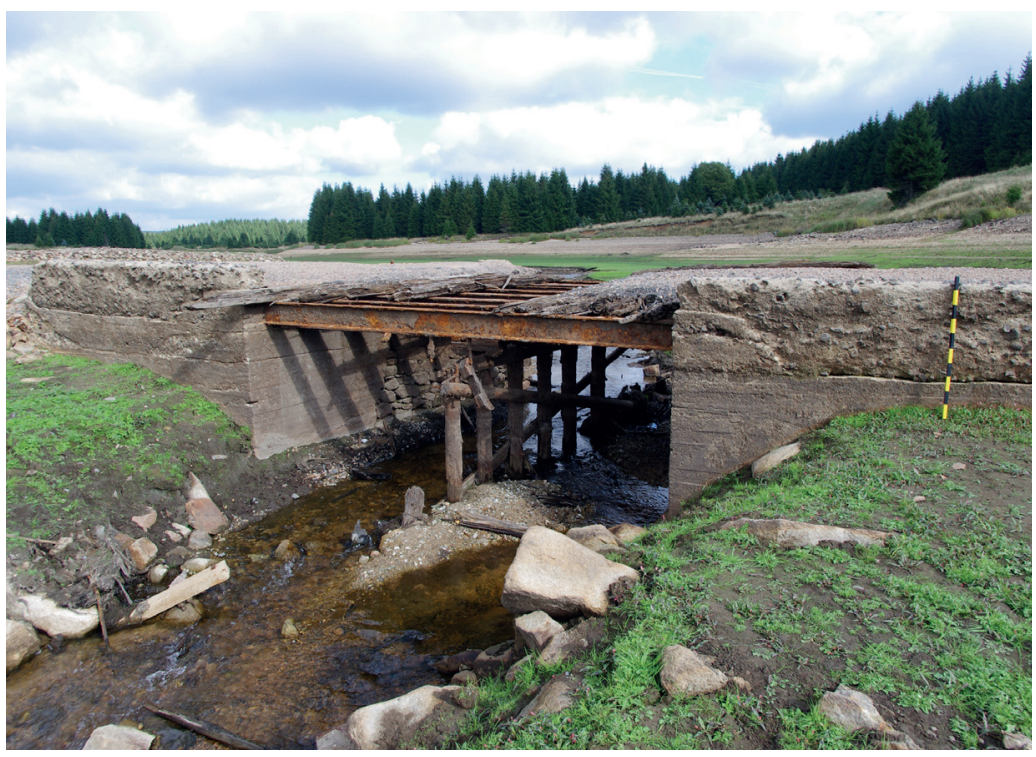

Obr. 4. Jeden ze dvou mostů v zaniklé vsi Fláje. Nalézá se na místě, které za normálních okolností bývá zaplavené (foto L. Funk, září 2015).

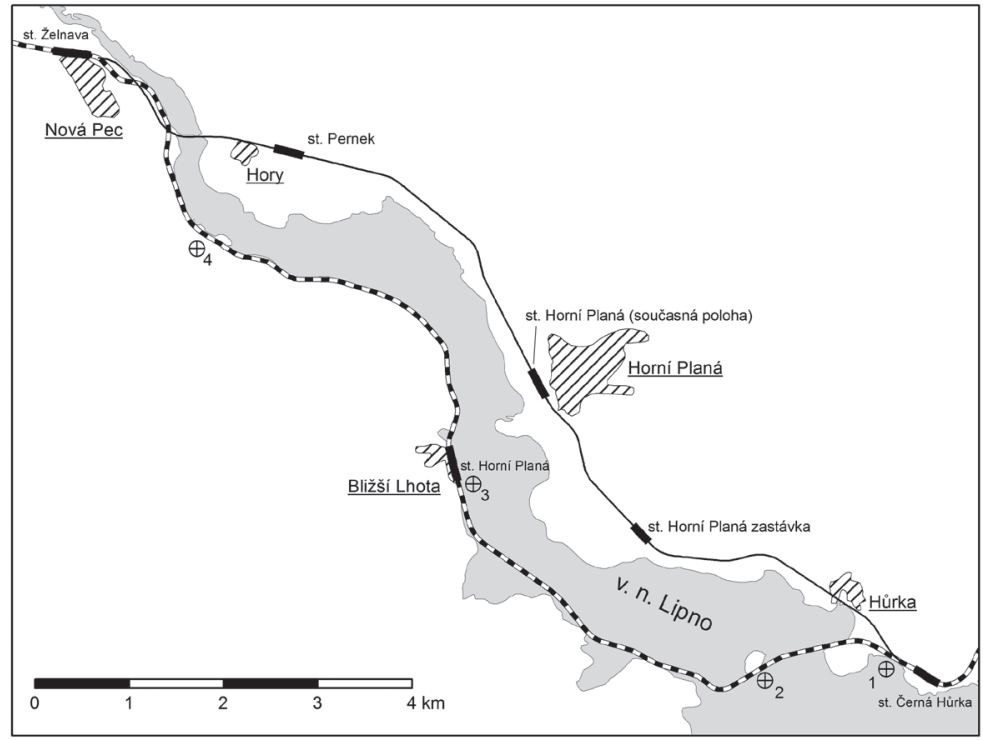

Obr. 5. Plán pošumavské železnice v oblasti vodní nádrže Lipno. Tlustou černobílou čarou je vyznačen původní průběh, tenkou spojitou nově vzniklá přeložka. Čísla označují zkoumané lokality.

V textu je popisováno především číslo 3 (zaniklé nádraží Horní Planá) a 4 (úsek železnice při jižním břehu nádrže) (grafika M. Váňa). 


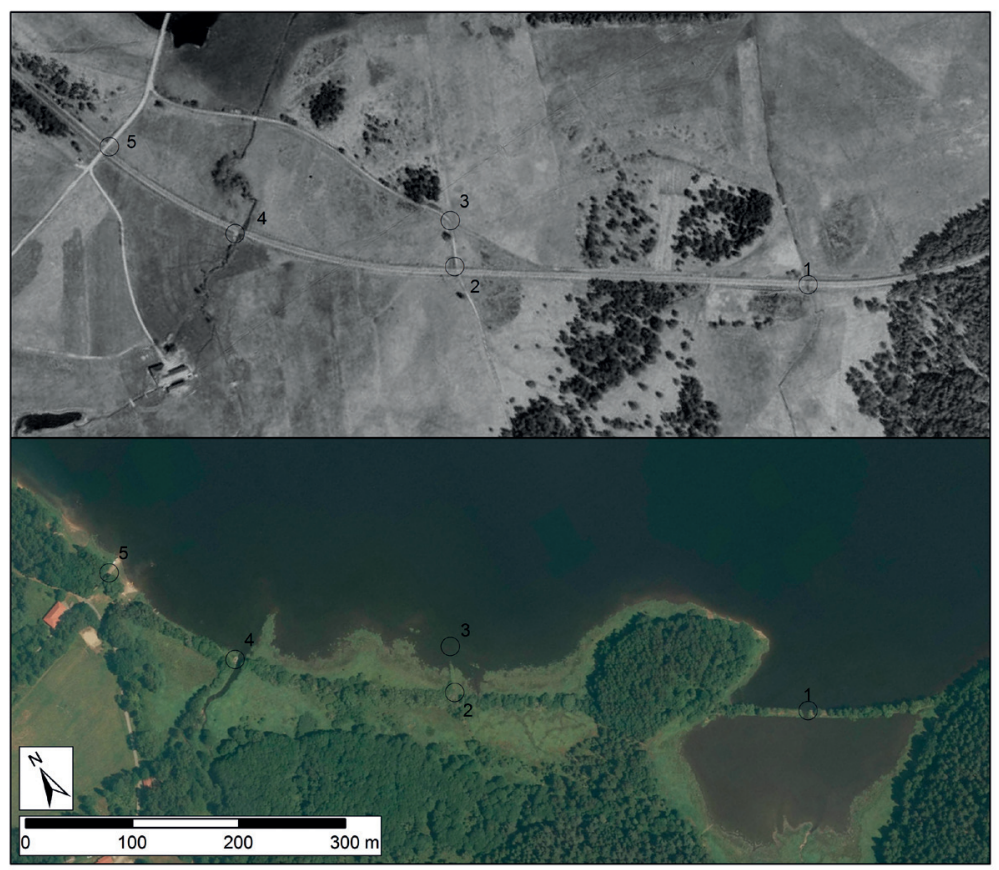

Obr. 6. Úsek zrušené železnice při jižním břehu nádrže. Nahoře snímek z roku 1947, dole současné ortofoto. Čísla označují dochované relikty: 1. most přes potok Šešovec, 2. přejezd, 3. rozcestí, 4. most přes Smrčinský potok, 5. přejezd. Násep se na spodním snímku projevuje jako rozpoznatelný pás zeleně

(historický snímek VHMÚ Dobruška, současné ortofoto ČÚZK, grafika M. Váňa).

Díky mírnému poklesu hladiny vodní nádrže bylo v době výzkumu možné prozkoumat i zaniklé nádraží u městečka Horní Blatná, které se za běžných okolností nalézá pod vodou. Zde se kromě železničního náspu zachovalo i několik pozůstatků nádražních budov. Ty mají podobu - obdobně jako relikty staveb v zaniklých Flájích - hald stavební suti, jež zachovávají půdorys a vnitřní členění původních domů (obr. 8).

\section{DÁLNIČNí MOSTY NA VODNÍ NÁDRŽI ŽELIVKA}

Plány na vybudování dálniční sítě sahají v Československu až do poloviny 30. let 20. století. Podle tehdejších návrhů vzešlých od státní správy a několika soukromých investorů (mezi nimiž byl i významný průmyslník Tomáš Bat’a) se uvažovalo o rychlostní silnici, která by procházela územím celého státu od jeho západní hranice až do Podkarpatské Rusi. Do těchto plánů však vstoupilo nucené odevzdání pohraničí po mnichovské dohodě a odtržení Slo- 


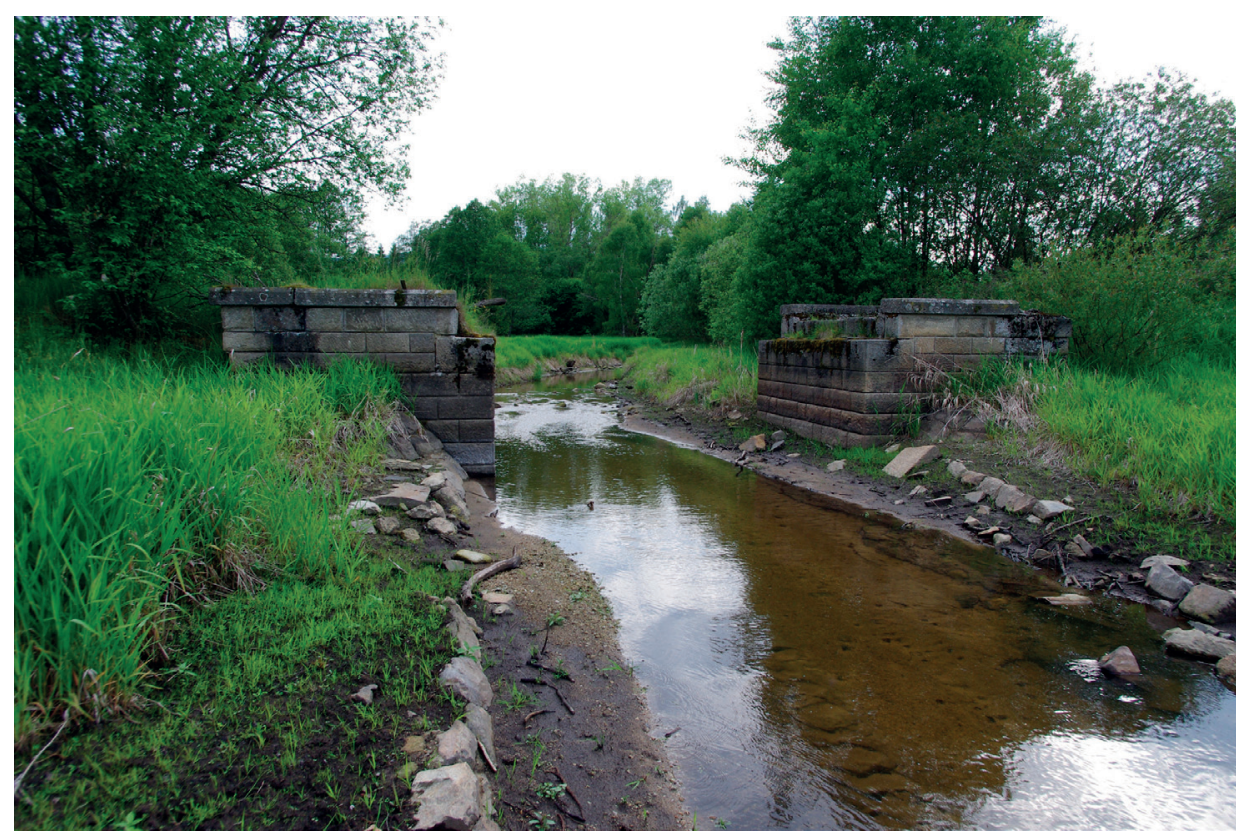

Obr. 7. Most přes Smrčinský potok. Pohled ze severovýchodu (foto L. Funk, červen 2014).

venska v březnu 1939. Když se tedy v květnu 1939 konečně začalo s výstavbou dálnice, byla její trasa oproti původním návrhům značně modifikovaná. Tato komunikace měla vést z Prahy do Brna a odtud ke slovenské hranici. Původně se počítalo, že se dálnice uvede do provozu již na konci roku 1940, strádání válečné ekonomiky však stavbu protahovalo, až se v roce 1942 rozhodlo o jejím přerušení. Po konci války se práce na dálnici obnovily, avšak nastupující komunistický režim neměl automobilovou dopravu mezi svými prioritami, a tak byla stavba v roce 1950 definitivně zastavena. Do té doby se z dálnice Praha - Brno - slovenská hranice stihlo vybudovat 77 km vozovky a 60 mostů. Navzdory odhadům komunistických plánovačů silniční doprava v průběhu let postupně rostla, a tak byl československý stát roku 1967 nucen obnovit výstavbu dálnice alespoň v úseku mezi Prahou a Brnem. Stavba této dálnice, jež dnes nese označení D1, byla dokončena roku 1980, tedy o 40 let později oproti předválečným plánům ${ }^{7}$.

Trasa dnešní dálnice respektuje původní plánovaný průběh a využívá všechny úseky a mosty dokončené do roku 1950; s výjimkou jediného místa. Souběžně s obnovou stavby dálnice se na přelomu 60. a 70. začala budovat i vodní nádrž

\footnotetext{
${ }^{7}$ http://www.dalnice.com (dostupné: 13.03.2017).
} 


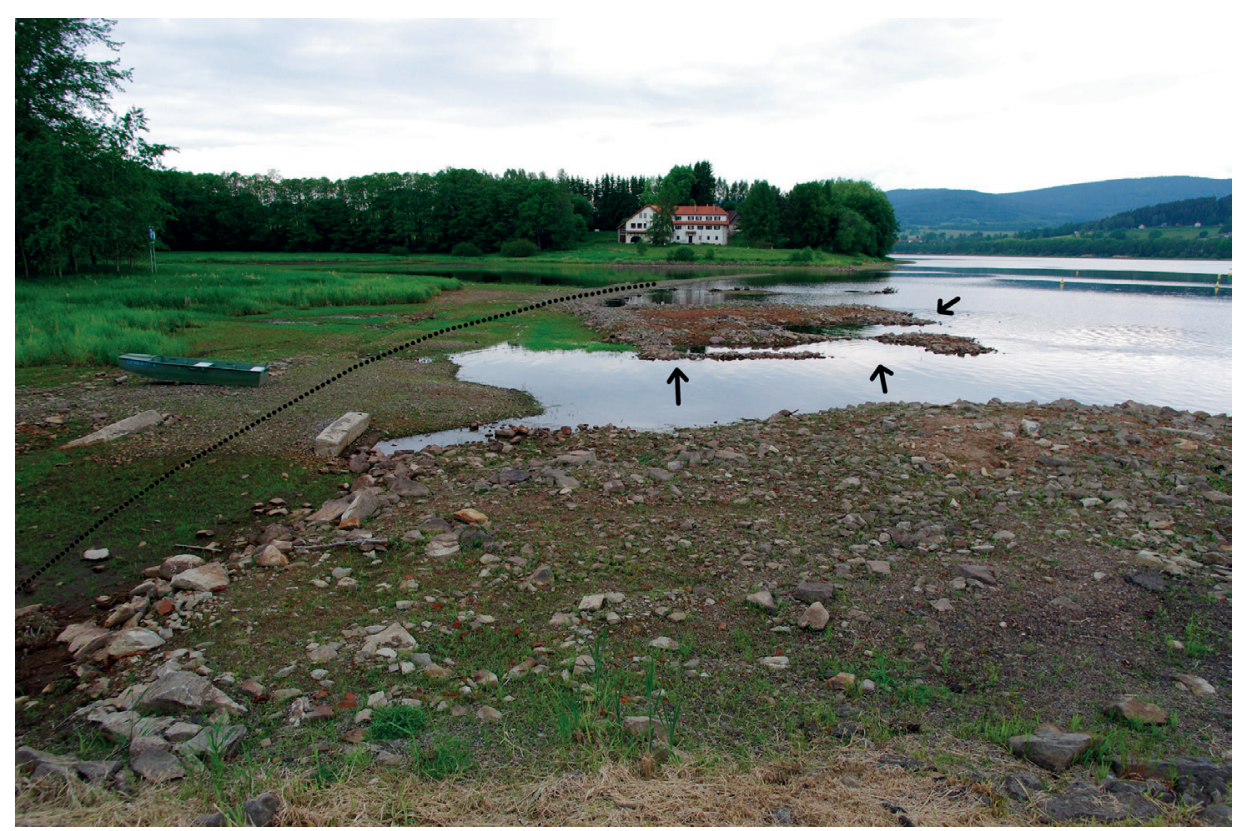

Obr. 8. Severní část nádraží Horní Planá. Tečkovanou čarou zvýrazněn průběh železniční trati, šipkami relikt budovy (foto L. Funk, červen 2014, grafika M. Váňa).

Želivka, která zaplavila mimo jiné i údolí Sedlického potoka a sousedního potoka Medulán nedaleko obce Borovsko, kde již od roku 1950 stály 2 dálniční mosty. Voda přehradního jezera vystoupala téměř až k povrchu mostovky. Protože pilíře ani jednoho z mostů nebyly původně projektovány na trvalé zaplavení, stalo by se jejich používání $\mathrm{k}$ dálničnímu provozu velmi nebezpečné, a tak musela být trasa dálnice $\mathrm{v}$ tomto místě odkloněna. Dva dálniční mosty tedy zůstaly opuštěny.

Menší z mostů (přes potok Medulán) dosahuje délky $37 \mathrm{~m}$ a spojuje dnes obě strany zatopeného údolí. Druhý most (přes Sedlický potok) je dlouhý $220 \mathrm{~m}$ (obr. 9). Z břehu je dnes přístupný jen ze směru od Prahy, na druhé straně končí uprostřed přehradního jezera, místo mostu tedy dnes připomíná spíše molo. Na obou mostech se dodnes zachovala spousta stavebních detailů, třeba jednoduše zdobená zábradlí nebo odtokové kanály na deštovou vody. Doklady po nedokončené dálnici nese i krajina $\mathrm{v}$ okolí mostů. Na hřebeni mezi oběma údolími lze pozorovat pokusy o jeho prokopání v podobě zářezů do obou stran svahu, které se zastavily na posledních zhruba 100 metrech. Terénní úpravy jsou patrné i vedle menšího mostu ve směru na Prahu, kde se dochovaly pozůstatky po nedokončeném náspu. 


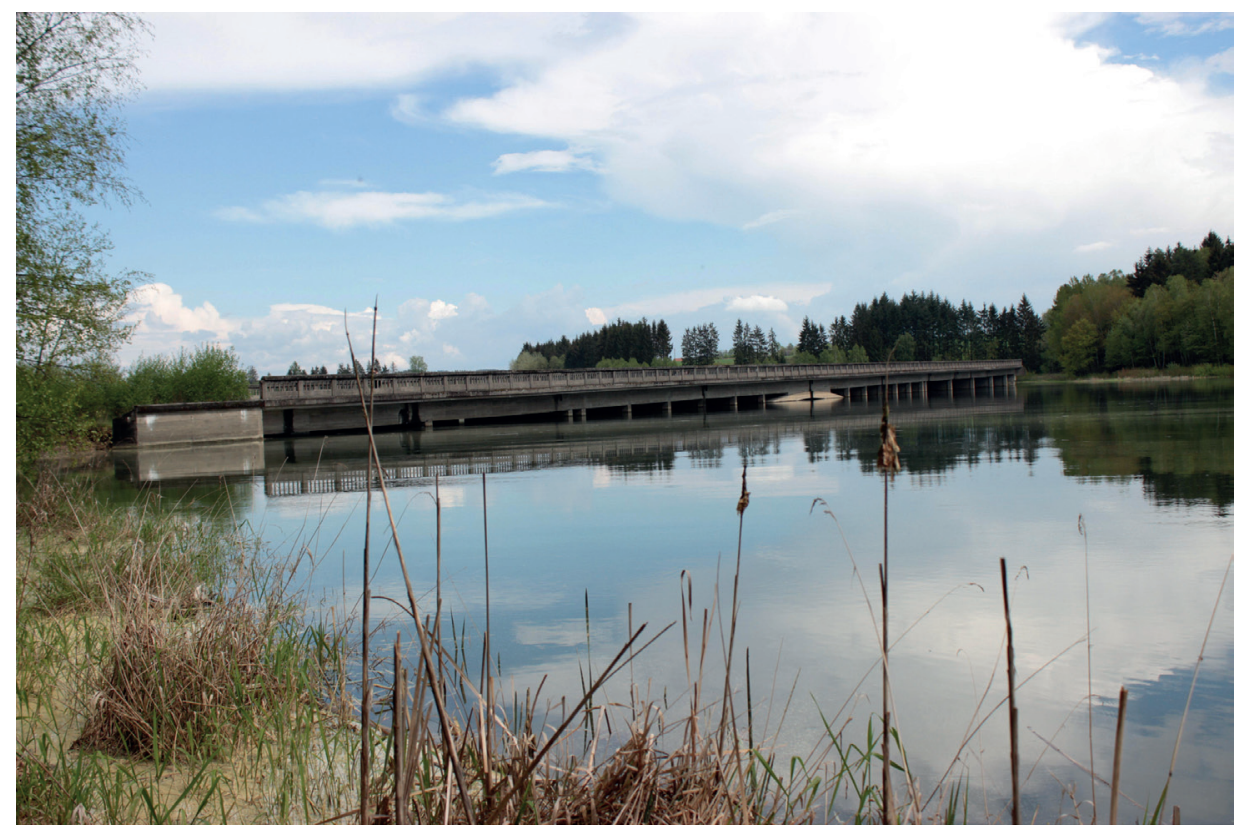

Obr. 9. Opuštěný dálniční most přes Sedlický potok je dnes téměř celý zaplaven vodní nádrží Želivka (foto J. Pařez, květen 2017).

\section{ZÁVĚR}

Výstavba vodních nádrží přinesla velký zásah do podoby české kulturní krajiny. Kromě obrovských zaplavených ploch kvůli nádržím také zanikly desítky vesnic a několik měst, zpřetrhaly se stovky kilometrů komunikací a zmizelo bezpočet větších i menších památek a pozůstatků po předchozí lidské činnosti. Tato studie se na př́íkladu tř́ lokalit pokoušela ukázat, že se krajiny v okolí vodních nádrží se svými hmotnými relikty z doby před výstavbou vodních děl mohou stát předmětem archeologického bádání. Zkoumání je možné podrobit objekty nacházející se mimo zaplavané území a za specifických okolností i ty, jež pohřbila vodní hladina. K výzkumu je však nutné přistoupit se znalostí specifik tohoto prostředí a přizpůsobit jim př́pravu a některé metody.

\section{Martin Váňa}

Tichá 12

31800 Plzeň, Czech Republic

e-mail:m.vana@seznam.cz 


\section{LiTERATURA}

Bureš M. (2012), Vesnice zaniklé po roce 1945 a kulturní krajina Novohradských hor, Disertační práce na Katedře archeologie Západočeské univerzity v Plzni.

Dolanský T. (2004), Lidary a letecké laserové skenování, Univerzita Jana Evangelisty Purkyně v Ústí nad Labem, Ústí nad Labem.

Firth A. (2010), Marine geophysics: integrated approaches to sensing the seabed, [in:] D. Cowley (ed.), Remote Sensing for Archaeological Heritage Management (=EAC Occasional Paper No. 5), Reykjavík, pp. 131-144.

Funk L. (2013), Zaniklé osídlení po roce 1945 jako archeologický pramen, Disertační práce na Katedře archeologie Západočeské univerzity v Plzni.

Joza V. (2002), Plavební kanál Fláje - Clausnitz v Krušných horách (= Der Flössgraben Fleyh - Clausnitz im Erzgebirge), Krušnohorská iniciativa, Mariánské Radčice.

Kolektiv (1978), Retrospektivní lexikon obci Československé socialistické republiky 1895-1970. Díl I. Svazek 1. Počet obyvatel a domů podle obci a částí obcí v letech 1895-1970 podle správniho členění k 1. lednu 1972, Federální statistický úr̆ad, Praha.

Pokorný D., Pešek V., Medunová A. (2006), Voda v ČR do kapsy, Praha, http://www. vitejtenazemi.cz/archiv/voda_cs/voda_cr.pdf (dostupné: 7.03.2017).

Rebstöck R. (2013), Šumavské koleje, Nakladatelství Dr. Radovan Rebsöck, Sušice.

Sýkorová J. (2002), Zmizelé domovy - Verschwundene Heimat, Státní okresní archiv Most, Most.

Váňa M. (2016), Archeologie vesnic zaniklých z dưvodu výstavby vodních nádrží, Západočeská univerzita v Plzni, Plzeň.

Vařeka P., Balý R., Funk L., Galusová L. (2008), Archeologický výzkum vesnic středověkého pưvodu na Tachovsku zaniklých po roce 1945, „Archaeologia Historica” 33, pp. 101-117.

\section{Internetové zdroje}

http://kontaminace.cenia.cz (dostupné: 7.03.2017).

http://lms.cuzk.cz/lms (dostupné: 7.03.2017).

http://podvodniarcheologie.cz (dostupné: 7.03.2017).

http://www.ceskatelevize.cz/porady/873537-hledani-ztraceneho-casu (dostupné: 7.03.2017).

http://www.dalnice.com (dostupné: 13.07.2017).

http://www.osac.cz (dostupné: 7.03.2017).

http://www.willyteam.cz (dostupné: 7.03.2017). 


\section{SUMMARY}

\section{ARCHAEOLOGY OF LANDSCAPES AFFECTED BY CONSTRUCTION OF WATER RESERVOIRS}

During the 20th century, 43 large water reservoirs were built on the territory of the present Czech Republic. These reservoirs have caused huge changes in cultural landscapes. Large areas have been flooded, many villages and towns have been deserted and many old communication tracts have been broken. There are many sources for studying these abandoned landscapes, such as pictures, photos, movies, old maps and military aerial photos from the $40 \mathrm{~s}$ and $50 \mathrm{~s}$. We can also examine the archaeological relics of former human activities.

This paper describes three examples of archaeological monuments that can be found in the landscapes transformed by water reservoirs. The first one is the ruin of the village of Fláje in the north of Bohemia. This village was founded in the Middle Ages and deserted in the 50 s due to the construction of the Fláje water dam. This reservoir destroyed about two-thirds of the village, but also the rest of the settlement was abandoned and destroyed when the drinking water protection zone was established. The field research of this site took place during the reconstruction of the dam when the water level was much lower than usual. That revealed dozens of relicts of demolished houses and other remnants of the deserted village.

Another example is the closed railway between the towns Černá Hưrka and Želnava in the Šumava mountains (southern part of Bohemia). This railway has been closed due to the construction of the largest water reservoir in the Czech Republic Lipno. Parts of the railway (in dry areas) were studied. Long sections of the rail bank with several structures (bridges, crossings, stations) were discovered with the use of old maps and aerial pictures.

The last example describes two concrete bridges of the main Czech highway between the two largest cities in the Czech Republic - Prague and Brno. The construction of the highway began in the 30s, but it was interrupted between the 40s and 60s. Meanwhile, the Želivka water reservoir has been built and it flooded part of the unfinished highway. The bridges of the highway are now abandoned in the middle of the lake.

The Czech landscapes of the large water reservoirs hide many remains of former human activities. Archaeology can provide useful tools for the research of the remains and for a better understanding of the history of those abandoned places. 
This paper describes three examples of archaeological monuments that can be found in landscapes transformed by water reservoirs. The first one is the ruin of the village Fláje in the north of Bohemia. This village was founded in the Middle Ages and deserted in the 50s due to the Fláje water dam. This reservoir destroyed about two-thirds of the village, but also the rest of the settlement was abandoned and destroyed due to the drinking water protection zone. The field research of this site took place during the reconstruction of the dam when the water level was much lower than usual. That revealed dozens of relict of demolished houses and other remnants of the deserted village.

Another example is the closed railway between towns Černá Hůrka and Želnava in the Šumava mountains (southern part of Bohemia). This railway has been closed due to the largest water reservoir in the Czech Republic Lipno. The parts of this railway (in dry areas) were studied. Long sections of the rail bank with several structures (bridges, crossings, stations) were discovered with help of old maps and aerial pictures.

The last example describes two concrete bridges of the main Czech highway between two largest cities in the Czech Republic Prague and Brno. Construction of this highway began in the $30 \mathrm{~s}$, but it was interrupted between $40 \mathrm{~s}$ and $60 \mathrm{~s}$. Meanwhile, the Želivka water reservoir has been built and it has flooded part of the unfinished highway. The bridges of the highway are now abandoned in the middle of the lake.

Czech landscapes of the large water reservoirs hide many remains of former human activities. Archaeology can provide useful tools for research of this remains and for a better understanding of the history of this abandoned places. 